\title{
Evaluation of Mineral Elements, Cyanide and Proximate Composition of Cassava (Mannihot Esculenta Crantz) From Ebony State, Nigeria.
}

\author{
${ }^{1}$ Madubuike P. C., ${ }^{2}$ Onyema, C.T., ${ }^{3}$ Odinma, S.C., and ${ }^{4}$ Sokwaibe C.E. \\ ${ }^{I}$ Projects Development Institute (PRODA) Enugu, Enugu State Nigeria. \\ ${ }^{2}$ Dept. of Pure and Industrial Chemistry, Nnamdi Azikiwe University Awka Anambra State Nigeria. \\ ${ }^{3}$ Dioceses of Nike Group of Schools, St. Cyprian's Sec. Sch. Abakpa Nike Enugu, Enugu State Nigeria. \\ ${ }^{4}$ Dept. of Chemistry, Alvan Ikoku Federal College of Education Owerri-Imo State Nigeria.
}

\begin{abstract}
Evaluation of the proximate, Cyanide and Mineral element composition were carried out on sweet cassava specie (Mannihot esculenta Crantz) from Ohaukwu and Iboko communities of Ebonyi State, Nigeria. Proximate analysis results of cassava specie from Ohaukwu gives: Crude protein (0.96\%), moisture $(5.00 \%)$, carbohydrate $(83.84 \%)$, Crude fibre $(7.60 \%)$, Ash $(2.00 \%)$, and Lipids $(0.60 \%)$. Its cyanide content was obtained as $1.91 \mathrm{mg} / \mathrm{kg}$, while the mineral elements composition were as follows, Ca $(0.28 \mathrm{mg} / \mathrm{kg})$, $\mathrm{Cu}(1.49 \mathrm{mg} / \mathrm{kg}), \quad \mathrm{Mn}(6.20 \mathrm{mg} / \mathrm{kg}), \quad \mathrm{Mg} \quad(0.50 \mathrm{mg} / \mathrm{kg}), \quad \mathrm{Na}(0.04 \mathrm{mg} / \mathrm{kg}), \quad \mathrm{Fe}(7.88 \mathrm{mg} / \mathrm{kg}), \quad \mathrm{Zn}(10.01 \mathrm{mg} / \mathrm{kg})$, $P b(0.25 \mathrm{mg} / \mathrm{kg}), C d(0.006 \mathrm{mg} / \mathrm{kg})$ and $K(5.28 \mathrm{mg} / \mathrm{kg})$. The cassava specie from Iboko had its proximate composition as follows: Crude protein (0.8\%), moisture (6.4\%), Crude fibre (7.35\%), Ash (2.40\%), Lipids $(0.34 \%)$, and Carbohydrate $(82.33 \%)$. While the Cyanide content was $(2.02 \mathrm{mg} / \mathrm{kg})$. its mineral element compositions were as follows; $\mathrm{Ca}(0.32 \mathrm{mg} / \mathrm{kg}), \mathrm{Mg}(0.54 \mathrm{mg} / \mathrm{kg}), \mathrm{Na}(0.03 \mathrm{mg} / \mathrm{kg}), \mathrm{Fe}(7.31 \mathrm{mg} / \mathrm{kg}), \mathrm{Zn}$ (8.03mg/kg), Mn (6.75 mg/kg), K (5.04mg/kg), Pb (0.23mg/kg), Cd (0.011 mg/ $/ \mathrm{kg})$, and $\mathrm{Cu}(1.50 \mathrm{mg} / \mathrm{kg})$.
\end{abstract}

Key Words: Mannihot esculenta Crantz, Proximate analysis and mineral compositions.

\section{Introduction}

Cassava (Mannihot esculenta Crantz) is a tropical, perennial plant that originated from Latin America. It is also a widely grown root crop in Brazil as well as in several other countries hence being the most stable food crop in tropical Africa. Its production is of vital importance both from a social and economic perspective according to regional plans of development. (Bernardo Ospina, et al., 2002). However, it is a crop with a primarily high carbohydrate content but with low protein content.

In the tropical regions, cassava is the most important root crop and as a source of energy for human consumption. It ranks fourth after rice, sugar cane and maize. It is a major source of carbohydrate for an estimated 500 million people in tropical Africa (Hillocks R.J., et al.,2002). One of its nutritional short comings is its potential toxicity due to its two cyanogenic glucosides content; lotaustrain and linamarin (Ravindran., et al., 1982). Roots and leaves of cassava contain the highest amount of linamarin. Linamarin produces the toxic compound hydrogen cyanide $(\mathrm{HCN})$ which can be hazardous to the consumer. Toxicity caused by free cyanide (CN) has already been reported while toxicity caused by glucoside has not. (Nartey et al., 1981). Meanwhile, linamarin and lotoaustrain Hydrolyze in the presence of acids and enzymes producing $(\mathrm{CN})$ and subsequently, (HCN) (O”Brien., et al., 1991). Cassava can be divided into two different principal types; sweet and bitter cassava, depending on the cyanide content. Although both varieties need to be detoxified before consumption through different types of treatments. Sweet cassava has low cyanide content compared to bitter cassava and could be consumed either freshly fried, baked, boiled or through other processing methods (Prosky et al., 1985). Meanwhile, in Brazil, cassava is broadly used in industry in the processing of a typical cassava floor named "Farinha". Also, recently,It has been reported about cassava flour of its use in Africa especially in the Southern Nigeria in the production of cassava bread. It is also gaining fast recognition as a good substitute for wheat flour in baking biscuits and fast food industries (Onwueme et al.,1978). Over the last 20 years, there has been tremendous recognition of the contributions that cassava can make to increasing incomes,population,produces more food for more people and generating employment opportunities in rural economy (Morgan, et al., 1959). Given its tremendous uses especially its consumption in form of food, there is need to evaluate its nutritive composition. (Proximate analysis), its cyanide content and mineral elements composition viza viz its safety for human consumption (Souci et al., 1994). 


\section{Experimental}

\subsection{Sample collection, identification and pre-treatment}

The cassava tubers (Mannihot esculenta Crantz) were obtained from farmlands located in Ohaukwu Local Government Area and Iboko located in Izzi Local Government Area all in Ebonyi State, Nigeria. They were identify by a taxonomist of the Botany Department of Nnamdi Azikiwe University Awka, Anambra State, Nigeria.

The cassava samples were washed before and after peeling using tap water and distilled water respectively. The sample were cut into small sizes and were air dried at room temperature for $30 \mathrm{mins}$. It was later oven dried with vaccum dry oven (model $267 \mathrm{pa}$ ) for $30 \mathrm{mins}$ at a temperature of $45^{\circ} \mathrm{C}$. The cassava samples were subsequently pounded with morter and pestle, stored in an air tight container for subsequent analyses.

\subsection{Proximate analysis}

Standard analytical procedures for food analysis were adopted in carrying out the determination of moisture content, crude protein, crude fibre and crude fats and while available carbohydrate was calculated by difference.

\section{Results And Discussion}

The results of the proximate composition, mineral element and cyanide content of Mannihot escu;enta Crantz from Ohaukwu and Iboko communities of Ebonyi State, Nigeria are summarized in Table 1-3.

\begin{tabular}{|c|c|c|c|c|c|c|}
\hline \multirow[t]{3}{*}{ Varities } & \multirow{2}{*}{\multicolumn{2}{|c|}{$\begin{array}{r}\text { Carbohydrates Crude } \\
\text { fibre }\end{array}$}} & \multicolumn{4}{|c|}{ Moisture Ash Crude Lipid } \\
\hline & & & \multirow[b]{2}{*}{$\%$} & \multirow[b]{2}{*}{$\%$} & \multicolumn{2}{|c|}{ protein } \\
\hline & $\%$ & $\%$ & & & $\%$ & $\%$ \\
\hline Ohaukwu & 83.84 & 7.60 & 5.00 & 2.00 & 0.96 & 0.60 \\
\hline Iboko & 82.53 & 7.35 & 6.4 & 2.40 & 0.88 & 0.34 \\
\hline \multicolumn{7}{|c|}{ Table 2: Mineral element content of Mannihot esculenta Crantz } \\
\hline Elements & $\begin{array}{l}\text { Ohaukwu } \\
(\mathrm{Mg} / \mathrm{kg})\end{array}$ & $\begin{array}{l}\text { Iboko } \\
(\mathrm{Mg} / \mathbf{k g})\end{array}$ & $\begin{array}{r}\text { WHO st } \\
(\mathrm{Mg}\end{array}$ & $\begin{array}{l}\text { adard } \\
\mathrm{kg} \text { ) }\end{array}$ & & \\
\hline $\mathrm{Ca}$ & 0.28 & 0.32 & 3.00 & & & \\
\hline $\mathrm{Mg}$ & 0.50 & 0.54 & & & & \\
\hline $\mathrm{Na}$ & 0.04 & 0.03 & & & & \\
\hline $\mathrm{Fe}$ & 7.88 & 7.31 & 10. & & & \\
\hline $\mathrm{Zn}$ & 10.01 & 8.03 & 15. & & & \\
\hline $\mathrm{Cu}$ & 1.49 & 1.50 & $1.5-3$ & & & \\
\hline $\mathrm{Mn}$ & 6.20 & 6.75 & & & & \\
\hline $\mathrm{K}$ & 5.28 & 5.04 & & & & \\
\hline $\mathrm{Pb}$ & 0.25 & 0.23 & $0.1-0$ & & & \\
\hline $\mathrm{Cd}$ & 0.006 & 0.0 & $0.1-0$ & & & \\
\hline
\end{tabular}

Table 3: Cyanide content of Mannihot esculenta Crantz

\begin{tabular}{llll}
\hline & Ohaukwu & Iboko & WHO (ppm) \\
\hline $\mathrm{Mg} / \mathrm{Kg}$ & 1.91 & 2.02 & 10.00 \\
\hline
\end{tabular}

From table 1, it was observed that the cassava sample from Ohaukwu was higher in all the food classes than those from Iboko except its moisture content $(5.00 \%)$ and ash $(2.00 \%)$ which were lower than $(6.40 \%)$ and $(2.40 \%)$ moisture and ash content respectively for Iboko samples.

Hence, it could be said that cassava sample from Ohaukwu has more nutritive value than those from Iboko.

The mineral element composition showed no particular trend but both samples contain some mineral elements which are essential for the body, though present in low concentration comparably with the recommended WHO standards. 
The very low concentration of heavy metals such as $\mathrm{Pb}$ and $\mathrm{Cd}$, and low Cyanide content of the samples makes it and its associated products such as cassava flour safe human consumption.

Comparatively, the Cyanide content of Iboko cassava sample indicated higher Cyanide content $(2.02 \mathrm{mg} / \mathrm{kg})$ than Ohaukwu cassava sample of $(1.91 \mathrm{mg} / \mathrm{kg})$.

\section{Conclusion And Recommendation}

From the above results, we can conclude and recommend that Ohaukwu cassava should be consumed more to those of Iboko cassava as it is of higher nutritional and mineral content value essential for human body development.

\section{References}

[1] Bernardo Ospina, I.A, Hernan Ceballes. (CIAT) 2002. Ha Yuca enel Tercer Milenie, Sistermas Modernes de Produccion procesaminento, Utilizacion and Commercialization. Bolivia Journal of Chem. Vol. 24(3)10.

[2] Hillocks R.J., Thresh J.M and Belloti A.C. (2002). Cassava: Biology production and Utilization CAB International., Vol 3 (41),50.

[3] Nartey F.,Vennesland B.,CONNEE., Knowles C.J., Wesley J.,Wissing F.,(1981), Cyanogensis in tropical feeds and feed stuffs, Academic press, London.pp 115-32.

[4] Morgan W.B.,(1959). Roots and the African food crisis(Influence of Europiean contacts on the landscape of Southern Nigerian). Geographical Journal Vol. 128 (48) 64.

[5] O"B M.G.,Taylor A.J., Poulter N.H.,(1991). Iproved enzymatic assay for cyanogens in fresh and processed cassava. Journal of Science food of Agric. Vol 56,(277)89.

[6] Onwueme I.C., (1978).,Tropical Tuber Crops. John Wiley and Sons Ltd. New- York. Chapt. 15 pp.150- 151.

[7] Prosky.(1985). Determination of Dietary fibre. Journal of Assoc. of Analytical Chem. Vol 68 (4)5.

[8] Ravindran V.,Kornegay, Webb J.R. K.E. and Rajaguru,A.S.B.(1982). Nutient Characterization of some feed stuffs of Sri Lanka. Journal of Nut. Agric. Soc Vol 19(19)32.

[9] Souci S.W, Fachman W.,Krant H.,(1994). Food Composition and Nutrition Tables Fifth Edition. Medpharm Scientific publishers Stuttgart,London.pp 1-3. 